ARQGA / 994

\title{
DETECTION OF
}

\section{HELICOBACTER PYLORI IN GASTRIC CANCER ${ }^{+}$}

\author{
Luana Paredes Leite de Barros PEREIRA ${ }^{1}$, Jaques WAISBERG ${ }^{2}$, \\ Eduardo Antonio ANDRÉ ${ }^{3}$, Arnaldo ZANOTO ${ }^{4}$, \\ João Paulo MENDES Jr. ${ }^{5}$ and Heloísa Prado SOARES ${ }^{6}$
}

ABSTRACT - Background and Objectives - Considering the high prevalence of stomach cancer in the northern region of Brazil and the recognized relationship between chronic gastric inflammation caused by Helicobacter pylori, and its carcinogenic potential, the objective we had with this study was to investigate the presence of the microorganism in macro and microscopic presentations of neoplasm in different regions of the stomach, and in non-malignant lesions concomitant to the adenocarcinoma in patients originating from the metropolitan area of Belém (State of Pará, Brazil). Methods Examinations were made on 172 patients divided into two groups: group I, formed by 75 patients with gastric carcinoma, and group II, formed by 97 patients with mild enanthematic gastritis, considered control group. The diagnosis was obtained during endoscopic examination and the respective biopsy. Gastric neoplasms were classified macroscopically in accordance with Borrmann's classification, and microscopically in accordance with Laurén's classification. In group I, 54 patients were male and 21 female while in group II, 22 patients were male and 75 female. The average age in group I was 61.2 years (range 27 to 86 years), while in group II it was 37.5 years (range 16 to 69 years). Thin sections were prepared and stained using the hematoxylin-eosin method. In the Helicobacter pylori research, the modified Gram stain was utilized. Statistical analysis was done by utilizing the chi-squared $\left(\chi^{2}\right)$ test, Mann-Whitney test (U), and Fisher's exact test. Results - The results showed the detection of Helicobacter pylori were significantly greater in patients with mild enanthematic gastritis than in patients with gastric carcinoma. The presence of Helicobacter pylori in patients with gastric carcinoma and mild enanthematic gastritis was significantly greater in the antral region than in other gastric regions. Helicobacter pylori detection in patients with gastric carcinoma did not present a significant difference in relation to the macroscopic aspect of the tumor either intestinal or diffuse histological types. Conclusions - These data suggest the presence of the bacteria is predominant in the antral region and it does not show relation with the macroscopic types or histological intestinal or diffuse types of gastric carcinoma.

HEADINGS - Helicobacter pylori. Helicobacter infections. Stomach neoplasms, etiology. Adenocarcinoma. Gastritis, atrophic.

Part of Master Thesis from the Postgraduate Course in Surgical Gastroenterology at the "Instituto de Assistência Médica do Servidor Público Estadual (IAMSPE)", São Paulo, SP, Brazil.

Gastroenterologist.

Department of Surgical Gastroenterology, Hospital do Servidor Público Estadual, São Paulo, SP.

Department of Clinic Gastroenterology, Hospital do Servidor Público Estadual, São Paulo, SP.

Center for Teaching and Research Development, IAMSPE.

Department of Surgery, Federal University of Pará, Belém, PA

ABC Medical School, Santo André, SP.

Address for correspondence: Dr. Jaques Waisberg - Rua das Figueiras 550 - apt. 134 - Bairro Jardim - 09080-300 - Santo André, SP. e-mail: jaqueswaisberg@uol.com.br 


\section{INTRODUCTION}

Stomach cancer is considered to be the second most frequent type of cancer and the second largest cause of death from cancer worldwide $^{(5,21,32,41)}$.

In Brazil, stomach cancer is the most frequent neoplasm of the digestive system, occupying first place in the scale of occurrence among males and fourth place among females ${ }^{(3,8)}$.

The State of Pará (PA) presents the greatest incidence of stomach cancer in Brazil ${ }^{(8,26)}$. In the metropolitan area of Belém, capital of the State, malignant neoplasms are the main cause of death, and stomach cancer represents the second largest cause of death from malignant disease among females and the first among males ${ }^{(26)}$.

Among the environmental factors that could favor the increase in incidence of this disease are the consumption of salty ${ }^{(13)}$, smoked, poorly preserved ${ }^{(26)}$ or burned foods, diets rich in nitrous compounds, tobacco abuse and the infection of the gastric mucosa by Helicobacter pylori (H.pylori) ${ }^{(29)}$.

H.pylori, considered to be a type I risk factor for carcinogenesis, is cited as the main cause of chronic antral gastritis, with a relationship having been proposed with gastric carcinogenesis, as an environmental co-factor $^{(4,30)}$. The microorganism is capable of inducing inflammatory responses in gastric tissue, in practically all human hosts, giving rise to a risk of development of multifocal gastritis, intestinal metaplasia and adenocarcinoma in the gastric corpus and antrum ${ }^{(23,31,42)}$.

Considering the high prevalence of stomach cancer in the northern region of Brazil and the recognized carcinogenic potential for inflammation of the mucosa that H.pylori has, the objective we had with this study was to investigate the presence of the microorganism in macro and microscopic presentations of neoplasm in different regions of the stomach, and in non-malignant lesions concomitant to the adenocarcinoma in patients originating from the metropolitan area of Belém.

\section{PATIENTS}

In the period between March 1996 and November 1997, 172 patients were examined, divided into two groups: group I, formed by 75 patients with gastric adenocarcinoma diagnosed by upper digestive tract endoscopy and confirmed by means of histopathological study; and group II, considered as control group, composed of 97 patients whose endoscopic examination demonstrated only mild enanthematic gastritis, according to Sidney's classification ${ }^{(11)}$. All the patients examined were from the metropolitan region of Belém. During the stages of performing the study, the following were considered to be criteria for exclusion: loss of the biopsy material collected, loss of the patient from the endoscopy services when needed to repeat the examinations, and the presence of other affections of the upper digestive tract diagnosed during endoscopic examination.
The presence of H.pylori in biopsies was studied initially in relation to the overall sample from the patients, and afterwards, in relation to samples matched by sex and age for 84 patients divided into 42 pairs.

The inclusion criterion for patients to be placed in group I was the presence of gastric carcinoma according to BORRMANN'S macroscopic classification $^{(7)}$ with its respective subtypes BI, BII, BIII and BIV, and LAURÉN'S microscopic classification ${ }^{(24)}$ with its respective intestinal and diffuse subtypes. For group II, the inclusion criterion was considered to be the presence of mild enanthematic gastritis, according to Sidney's classification for macro and microscopic aspects.

In group I (adenocarcinoma) 54 patients ( $72 \%$ ) were male and 21 female (28\%). In group II (gastritis), the distribution was 22 male patients $(22.7 \%)$ to 75 female $(77.3 \%)$.

Considering the two groups together, the average age was 47.84 ( 16 to 86 years) and the median age was 46.50 (16 to 86 years). In group I, the average age was 61.21 (27 to 86 years) and the median age was 65 years. In group II, the average age was 37.51 (16 to 69 years) and the median 34 years.

\section{METHOD}

While performing the endoscopic examination, fragments of the gastric mucosa were obtained via biopsy. For the patients in group I, six to eight biopsy fragments were removed from the lesion suspected of having neoplasm, for the histopathological examination. Two fragments of the mucosa of the antrum, about $2 \mathrm{~cm}$ from the pylorus, and one fragment from the gastric corpus, were removed for researching H.pylori and studying the histopathology. The same procedure was performed for researching H.pylori in the patients of group II.

The material collected from the two groups was placed in flasks with formol buffered at $10 \%$, for fixing, and was then processed for histological examination and set into paraffin blocks. The sample sections were made at a thickness of $5 \mu$ using a microtome, prepared on slides and stained using the hematoxylin-eosin method (HE) for histopathological examination under the optical microscope. For the investigation of H.pylori, the modified Gram method was utilized (lugol solution at $1 \%$ with gentian violet solution at $2.5 \%$ ).

The statistical analysis was performed using the chi-squared $\left(\chi^{2}\right)$, Cochran (G), Mann Whitney (U) and Fisher exact tests. In all the tests, the level for the rejection of the null hypothesis was set at $0.05 \%$ (significance level of $95 \%$ ), in accordance with the current standards in biological studies, with the significant values being signaled with an asterisk $(*)$.

\section{RESULTS}

Among the 54 patients in group I (carcinoma), H.pylori was identified in $39(52.0 \%)$. There was no statistically significant 
difference in the values found among these patients in comparison with patients without the presence of the microorganism $(P=0.82)$. From the matching of the cases in relation to age and sex, the results exhibited a statistically significant difference $(P=0.00618)$ (Table 1$)$.

Among the patients in group II (gastritis), H.pylori was identified in 72 of them $(74.2 \%)$, whereas in the other $25(25.7 \%)$ the microorganism was not encountered in the gastric biopsies. A statistically significant difference was demonstrated among the values found ( $P=0.0042)$, and from the matching of the cases in relation to age and sex, the results also exhibited a statistically significant difference $(P=0.00618)$ (Table 1$)$.

With regard to the localization of the carcinoma in the stomach, it was observed that 39 patients presented an antral lesion (52.0\%), 23 with a corporal lesion (30.6\%), 11 with antral and corporal lesions (14.6\%), one with antral, corporal and fundic lesions (1.3\%) and another with only a fundic lesion $(1.3 \%)$.

In the patients of group I (carcinoma) and group II (gastritis), the presence of H.pylori, independent of the localization of the gastric lesion, was significantly predominant in the antral region $(53.9 \%$ and $75.0 \%$, respectively) $(P<0.01)$. When the affection extended to more than one gastric region, for the group I (carcinoma) patients, H.pylori occurred most frequently in the corpus-fundus region $(35.9 \%)$, and for the group II (gastritis) patients, the microorganism was predominantly in the antrum-corpus region (23.6\%) (Table 2).
Analyzing the presence or absence of H.pylori in relation to the different macroscopic types of gastric carcinoma, according to BORRMANN'S classification, for the group I patients, it was observed that H.pylori was present in 39 of the patients $(52.0 \%)$, whereas in $36(48.0 \%)$ the microorganism was not identified. There was no statistically significant difference between the whole number of patients and among the different types of lesion in BORRMANN'S classification with regard to the presence or absence of H.pylori in gastric biopsies $(P=0.54)$.

Among the 75 patients in group I, the gastric adenocarcinoma was of intestinal type in $44(58.6 \%)$ patients and diffuse type in 31 (41.3\%), according to LAURÉN'S classification. There was presence of H.pylori in the gastric biopsies of the intestinal-type gastric carcinoma of 21 patients $(48.8 \%)$. In the gastric biopsies of patients with diffuse-type gastric carcinoma, there was identification of the microorganism in 18 (58\%), a result that did not present a significant difference. When the patients of both subgroups were evaluated, matched according to age and sex, again no significant difference was observed $(P>0.05)$.

Histopathological alterations of the gastric mucosa concomitant with the neoplasm were found in all the patients in group I. Thus, chronic gastritis was present in 37 of the patients, chronic gastritis and intestinal metaplasia in 36 , chronic gastritis and atrophy of the gastric mucosa in one, and chronic gastritis, intestinal metaplasia and

TABLE 1 - Presence or absence of Helicobacter pylori in the patients of group I (carcinoma) and group II (gastritis), matched by age and sex

\begin{tabular}{lcccccc}
\hline Group & $\begin{array}{c}\text { Helicobacter pylori } \\
\text { present }\end{array}$ & $\begin{array}{c}\text { Helicobacter pylori } \\
\text { absent }\end{array}$ & Total \\
\hline Carcinoma & $\mathrm{n}$ & $\%$ & $\mathrm{n}$ & $\%$ & $\mathrm{n}$ & $\%$ \\
Gastritis & 21 & 55.3 & 17 & 44.7 & 38 & 100 \\
Total & 39 & $84.8 *$ & 7 & 15.2 & 46 & 100 \\
\hline $\mathrm{n}=$ number of patients & 60 & 100 & 24 & 100 & 84 & 100 \\
\end{tabular}

TABLE 2 - Presence of Helicobacter pylori in the patients of group I (carcinoma) and group II (gastritis), according to the localization of the gastric lesion

\begin{tabular}{lcccccc}
\hline Localization & \multicolumn{2}{c}{ Gastritis } & \multicolumn{2}{c}{ Carcinoma } & \multicolumn{2}{c}{ Total } \\
\hline & $\mathrm{n}$ & $\%$ & $\mathrm{n}$ & $\%$ & $\mathrm{n}$ & $\%$ \\
Antrum & 54 & $75^{*}$ & 21 & 53.9 & 75 & 100 \\
Antrum + Corpus & 17 & 23.6 & 4 & 10.3 & 21 & 100 \\
Corpus + fundus & 1 & 1.4 & 14 & 35.9 & 15 & 100 \\
Total & 72 & 100 & 39 & 100 & 111 & 100 \\
\hline
\end{tabular}

$\mathrm{n}=$ number of patients

* = significant $(P=0.000002)$ 
atrophy of the gastric mucosa in another patient (Table 3). When the presence of the different non-malignant lesions of the gastric mucosa found among the patients of group I was related to the intestinal and diffuse types of gastric carcinoma, there was no statistically significant difference $(P=0.24)$.

Of the 37 patients of group I with associated gastritis, the presence of H.pylori in the gastric biopsies was observed in 22 patients (59.4\%). When the gastric lesions encountered were chronic gastritis and intestinal metaplasia, the presence of the microorganism was observed in 15 of the 37 patients (42.8\%). In one patient (1.3\%), in whom the non-malignant lesions encountered were chronic gastritis and atrophy of the gastric mucosa, the presence of H.pylori was demonstrated in the gastric biopsy, with the same occurring with another patient $(1.3 \%)$ of the same group with chronic gastritis, intestinal metaplasia and atrophy of the gastric mucosa. The values obtained did not show a statistically significant difference $(P=0.47)$ (Table 3).

\section{DISCUSSION}

In Latin America, Brazil is highlighted by its annual indices of gastric carcinoma incidence, which exceed 45 cases per 100,000 inhabitants $^{(2,30)}$. The present study was performed in the city of Belém, capital of the State of Pará, which leads the statistics of gastric adenocarcinoma incidence in $\mathrm{Brazil}^{(2,26)}$.

The intestinal type of gastric carcinoma has been found established as the most frequent type in areas with elevated indices of infection by H.pylori and in less favored populations ${ }^{(12,19,27,28,38,39)}$. Although the city of Belém has these characteristics, no prevalence of the intestinal type of gastric carcinoma was brought into evidence in this study, in relation to the diffuse type, just as there was an absence of significant difference in the distribution of patients when BORRMANN'S macroscopic classification and LAURÉN'S microscopic classification for gastric carcinoma were compared.
In our sample, we observed a predominance of H.pylori among the patients with a median age of less than 46 years. As these patients were younger, the chronic inflammation was generally not accompanied by atrophy (antral form), and the normal acid secretion provided a microenvironment suitable for the development of H.pylori, contrary to atrophy conditions, in which the secretion of hydrochloric acid decreases, and conditions become rather unsuitable for H.pylori $i^{(6,10}$, 18, 25).

In the present study, there was a significant predominance of neoplastic lesions in the antral region, in relation to the gastric corpus and fundus regions. However, when we compared the detection of H.pylori in the diverse gastric localizations for adenocarcinoma, no significant difference was obtained, even when the samples compared were matched by age and sex, despite the antral lesions being more frequent than proximal lesions.

Our data is sustained by the model proposed by CORREA ${ }^{(15)}$, in which the non-neoplastic lesions represented by chronic gastritis, intestinal metaplasia and atrophy of the gastric mucosa, either in association or in isolation, in patients with gastric adenocarcinoma, can represent part of the model proposed for human gastric carcinogenesis.

A study made by CAHILL et al. ${ }^{(9)}$ suggested that the infection by H.pylori was not capable of modifying the gastric epithelial cell proliferation in patients with pre-malignant lesions or even with gastric adenocarcinoma, signaling that, although H.pylori performs a role in gastric carcinogenesis, the microorganism apparently does not exercise an influence in the locally advanced stages of the disease. This fact aids the comprehension, in the present study, of the finding of low detection of H.pylori in biopsies of patients with gastric adenocarcinoma that consisted, in its majority, of macroscopically advanced lesions (Borrmann III). On the other hand, it was seen, in concordance with the recognition of the inflammation of the gastric mucosa caused by H.pylori, that its presence in gastric biopsies of patients with enanthematic gastritis was significantly greater than for patients with

TABLE 3 - Presence or absence of Helicobacter pylori in non-malignant lesions of the gastric mucosa in patients of group I (carcinoma)

\begin{tabular}{|c|c|c|c|c|c|c|}
\hline \multirow[t]{2}{*}{ Gastric lesions } & \multicolumn{2}{|c|}{$\begin{array}{c}\text { Helicobacter pylori } \\
\text { present }\end{array}$} & \multicolumn{2}{|c|}{$\begin{array}{c}\text { Helicobacter pylori } \\
\text { absent }\end{array}$} & \multicolumn{2}{|c|}{ Total } \\
\hline & $\mathrm{n}$ & $\%$ & $\mathrm{n}$ & $\%$ & $\mathrm{n}$ & $\%$ \\
\hline$A+B$ & 15 & 42.8 & 21 & 57.1 & 36 & 100 \\
\hline $\mathrm{A}+\mathrm{C}$ & 01 & 100 & 00 & - & 01 & 100 \\
\hline
\end{tabular}

$\mathrm{A}=$ chronic gastritis; $\mathrm{B}=$ intestinal metaplasia; $\mathrm{C}=$ atrophy of the mucosa

n = number of patients $P=0.47(\mathrm{NS}) \quad \mathrm{NS}=$ not significant 
gastric adenocarcinoma, including when the samples were analyzed matched by sex and age.

Atrophy of the stomach mucosa is characterized by the accentuated reduction in the epithelial thickness, while adenocarcinoma represents excessive replication and anarchy of this epithelium ${ }^{(16,17}$, ${ }^{35,40)}$. In the present study, chronic gastritis was found in the gastric biopsies of all the patients with gastric adenocarcinoma, raising the possibility of a precursory condition in the genesis of this type of neoplasia.

We must emphasize that in our sample, different from what was expected, the presence of H.pylori in the gastric biopsies of patients with intestinal-type gastric adenocarcinoma did not present a statistically significant difference when compared with patients with the diffuse type, including when these were matched by age and sex, considering the assertion that H.pylori is related to the genesis of intestinal-type gastric adenocarcinoma. On possible explanation for this fact is that the patients in this study who were suffering from diffuse-type gastric adenocarcinoma may have contracted the H.pylori infection in connection with their socioeconomic conditions and their region of origin (State of Pará), which has the highest rates of infection by this microorganism in Brazil ${ }^{(1,2)}$. We emphasize, however, that the possibility cannot be excluded that biological factors particular to the neoplasm or related to the oncogenesis may have influenced such findings.

Patients with gastritis caused by H.pylori and intestinal metaplasia show an increase in epithelial cell proliferation when compared to normal mucosa $a^{(9,34,35)}$. On the other hand, the diffuse type of gastric adenocarcinoma appears not to be related to gastritis and intestinal metaplasia $^{(35)}$. Despite these observations, in the present study no significant differences were seen between the number of patients with gastritis, intestinal metaplasia and atrophy of the gastric mucosa, and the presence of intestinal or diffuse-type adenocarcinoma. It is possible that other participatory factors in the genesis of diffusetype gastric adenocarcinoma may have influenced these results, and that the alterations in the gastric mucosa observed in these cases were consequent to determinants of a genetic nature.

It must be stressed, nevertheless, that despite all the patients in the study with gastric adenocarcinoma exhibiting chronic gastritis, the results obtained showed that only $2.6 \%$ of the patients presented gastric adenocarcinoma associated with atrophy of the gastric mucosa, whereas intestinal metaplasia was present in approximately $48 \%$ of these patients. The non-malignant alterations in the gastric mucosa (chronic gastritis, intestinal metaplasia and atrophy of the gastric mucosa) found in the patients were not significantly different in relation to the intestinal and diffuse types of gastric adenocarcinoma.

It is considered that intestinal metaplasia normally results from the gastric inflammation induced by chronic infection by H.pylori ${ }^{(14}$, 18, 33, 36). ENDO et al. ${ }^{(18)}$ observed that atrophic chronic gastritis and intestinal metaplasia are more frequent in the mucosa adjacent to intestinal-type adenocarcinoma. Nevertheless, in the data of the present study, no significant difference was encountered between the presence of H.pylori in the stomachs of patients with intestinal or diffusetype gastric adenocarcinoma.

Clinical studies have shown greater detection rates for H.pylori in tissue from areas adjacent to gastric adenocarcinoma that is sectioned or undergoes biopsy of its lesions, than among patients without adenocarcinoma $^{(10,20,22,37)}$. In the present study, the number of patients with gastric adenocarcinoma in whom the presence of H.pylori was observed in the areas of chronic gastritis was not significantly different from the number of patients with gastric neoplasm in which H.pylori was not identified. In the same way, there was no significant difference in the detection of H.pylori in gastric biopsies between the different macroscopic forms of gastric adenocarcinoma of BORRMANN'S classification. In addition to this, the detection of H.pylori was similar in both the patients with gastric adenocarcinoma and those with superficial inflammation of the mucosa.

ENDO et al. ${ }^{(18)}$ reported that the prevalence of H.pylori in nonmalignant tissue adjacent to intestinal-type carcinoma was not significantly different from the malignant tissue adjacent to the diffuse type. This was corroborated in the present study, in which the presence of H.pylori in gastric biopsies of patients with gastric adenocarcinoma, even when matched by age and sex, did not demonstrate a significant difference between the intestinal and diffuse types.

The frequency of atrophic chronic gastritis encountered in this work was not different between the intestinal and diffuse types of adenocarcinoma. This result suggests that the finding of H.pylori in non-malignant tissue adjacent to carcinoma is associated with atrophic chronic gastritis and not with the intestinal or diffuse histopathological pattern.

Given the interdependence of etiological factors in the process of gastric carcinogenesis, it is possible that the control of the infection by H.pylori may diminish the aggression of at least one of the carcinogenic factors. Thus, the recognition of gastric infection by H.pylori has ushered in a new era in the elucidation of the pathogenesis of gastric carcinoma. There is, however, a need for additional clarifications to define the populations at risk of gastric carcinoma and furnish strategies for selection and eradication of infection by H.pylori.

\section{CONCLUSIONS}

The analysis of the results from the detection of H.pylori in gastric biopsies of patients with gastric adenocarcinoma and patients with mild enanthematic gastritis has permitted the conclusion that the detection of H.pylori was significantly greater in patients who presented inflammation of the gastric mucosa. There was not, 
however, any statistical difference with regard to the presence or absence of the microorganism in the distinct types of carcinoma of the stomach, according to the classifications utilized. In relation to the localization of the microorganism in the diverse regions of the stomach in the two groups, it was detected preferentially in the antrum, attaining a level of statistical significance in relation to the corpus and fundus $(P<0.01)$. The identification of H.pylori in patients with concomitant adenocarcinoma and chronic gastritis was greater than in patients with gastric adenocarcinoma with intestinal metaplasia, although this did not attain a statistically significant difference.

Pereira LPLB, Waisberg J, André EA, Zanoto A, Mendes Jr JP, Soares HP. Detecção do Helicobacter pylori no câncer gástrico. Arq Gastroenterol 2001;38(4):240-246.

RESUMO - Racional e Objetivos - Considerando a elevada prevalência de câncer gástrico na região norte do Brasil e a conhecida relação entre a inflamação por gastrite crônica causada pelo Helicobacter pylori e seu potencial carcinogênico, os objetivos deste estudo foram detectar a presença do microorganismo nas apresentações macro e microscópicas da neoplasia nas diferentes regiões do estômago, e nas lesões não-malignas concomitantes ao adenocarcinoma, em doentes oriundos da área metropolitana de Belém (Estado do Pará, Brasil). Método - Foram examinados 172 doentes divididos em dois grupos: grupo I, constituído por 75 enfermos com carcinoma gástrico e grupo II composto por 97 doentes com gastrite enantemática leve, considerado grupo controle. Os diagnósticos foram obtidos por meio de exame endoscópico e respectiva biopsia. As neoplasias gástricas foram classificadas macroscopicamente de acordo com a classificação de Borrmann e microscopicamente de acordo com a classificação de Laurén. No grupo I, 54 doentes eram do sexo masculino e 21 do sexo feminino. No grupo II, 22 enfermos eram masculinos e 75 femininos. A média de idade no grupo I foi de 61,2 anos (27 a 86 anos) e a do grupo II foi de 37,5 anos (16 a 69 anos). As lâminas foram preparadas e coradas pelo método da hematoxilina e eosina, utilizando-se o método de Gram modificado na pesquisa do H.pylori. A análise estatística foi realizada com os testes do $\chi^{2}$, teste de Mann Whitney e teste exato de Fisher. Resultados - A deteç̧ão do H.pylori foi significativamente maior nos doentes com gastrite enantemática leve do que nos enfermos com adenocarcinoma gástrico. A presença do H.pylori nos doentes com adenocarcinoma gástrico e nos enfermos com gastrite enantemática leve foi significativamente maior na região antral do que nas demais localizações gástricas. A presença do H.pylori nos doentes com adenocarcinoma gástrico não apresentou diferença significativa em relação aos tipos macroscópicos ou com os tipos microscópicos intestinal ou difuso do tumor. Conclusões - Estes dados sugerem que a presenças do H.pylori em doentes com adenocarcinoma gástrico é predominante no antro e não apresenta relação com os subtipos macroscópicos ou histológicos do carcinoma gástrico.

DESCRITORES - Helicobacter pylori. Neoplasias gástricas. Gastrite atrófica. Adenocarcinoma. Neoplasias, etiologia.

\section{REFERENCES}

1. Araujo MT, Lima MP. Bactérias espiraladas em material de biópsia gástrica em Belém do Pará. Rev Pará-Médico 1989;13:21-2.

2. Araujo MTF, Alves Jr JM, Araujo R, Makino E, Khawage S. Frequency of Helicobacter pylori in gastric cancer patients in Belém, Pará, Brazil. ABCD Arq Bras Cir Dig 1993;8:92-5.

3. Arruda SMB, Jucá NT, Oliveira EP, Macedo FM, Albuquerque MC, Pereira MG. Perfil do câncer gástrico no Hospital das Clínicas da Universidade Federal de Pernambuco. GED Gastroenterol Endosc Dig 1997;16:14-8.

4. Asaka M, Takeda H, Sugiyama T, Kato M. What role does Helicobacter pylori play in gastric cancer? Gastroenterology 1997;13:S56-S60.

5. Barker DJP, Coggon D, Osmond C, Wickham C. Poor housing in childhood and high rates of stomach cancer in England And Wales. Br J Cancer 1990;61:5758 .

6. Blaser MJ, Chyou PH, Nomura A. Age at establishment of Helicobacter pylori infection and gastric carcinoma, gastric ulcer, and duodenal ulcer risk. Research 1995;55:562-5.

7. Borrmann R, Henke F, Lubarsch O. Handbuch der speziellen pathologischen anatomie und histologie. Berlin: Julius Springer; 1926. v.4, p.865.

8. Brasil. Ministério da Saúde. Secretaria Nacional de Assistência à Saúde. Instituto Nacional do Câncer, Coordenação de Programas de Controle de Câncer - ProOnco. Câncer Brasil - dados dos registros de base populacional. Rio de Janeiro: Instituto Nacional do Câncer; 1995. p.59-67.
9. Cahill RJ, Kilgallen C, Beattie S, Hamilton H, O'morain C. Gastric epithelial cell kinetics in the progression from normal mucosa to gastric carcinoma. Gut 1996;38:177-81.

10. Caruso ML, Fucci L. Histological identification of Helicobacter pylori in early and advanced gastric cancer. J Clin Gastroenterol 1990;12:601-2.

11. Castro LP, Oliveira CA, Prolla JC, Magalhães AFN, Resende JM. Sistema Sydney: uma nova classificação das gastrites. GED Gastroenterol Endosc Dig 1991;10:75-82.

12. Coelho LGV, Das SS, Karim QN, Walker MM, Queiroz DMM, Mendes EM, Lim JR. GF, Oliveira CA, Baron JH, Castro LP. Campylobacter pyloridis in the upper gastrointestinal tract: a Brazilian study. Arq Gastroenterol 1987;24:5-9.

13. Coggon D, Acheson ED. The geography of cancer of the stomach. Br Med Bull 1984;40:335-41.

14. Correa P, Fox P, Fontham E, Ruitz B, Lin Y, Zavala D. Helicobacter pylori and gastric carcinoma. Cancer 1990;66:2569-74

15. Correa P. Human gastric carcinogenesis: a multistep and multifactorial process Cancer Res 1992;52:6735-40.

16. Correa P, Shiao YH. Phenotypic and genotypic events in gastric carcinogenesis Cancer Res 1994;54:1941s-3s.

17. Correa P, Miller MJS. Helicobacter pylori and gastric atrophy: cancer paradoxes. J Natl Cancer Inst 1995;87:173-4.

18. Endo S, Ohkusa T, Saito Y, Fujiki K, Okayasu I, Sato C. Detection of Helicobacter pylori in early stage gastric cancer. Cancer 1995;75:2203-8.

19. Eurogast Study Group. An international association between Helicobacter pylori infection and gastric cancer. Lancet 1993;341:1359-62. 
20. Fox JG, Correa P, Taylor NS, Zavala D, Fontham E, Janney F. Campylobacter pylori-associated gastritis and immune response in a population at increased risk of gastric carcinoma. Am J Gastroenterol 1989;84:775-81.

21. Fuchs CS, Mayer RJ. Gastric carcinoma. N Engl J Med 1995;333:32-41.

22. Jaskiewicz K, Louwrens HD, Woodroof CW, Vanwyk MJ, Price SK. The association of Campylobacter pylori with mucosal pathological changes in population at risk for gastric cancer. S Afr Med J 1989;75:417-9.

23. Karnes WE Jr, Samloff IM, Siurala M, Kekki M, Sipponen P, Kin SW. Positive serum antibody and negative tissue staining for Helicobacter pylori in subjects with atrophic body gastritis. Gastroenterology 1991;101:167-74.

24. Laurén P. The two histological main types of gastric carcinoma: an attempt at a histo-clinical classification. Acta Pathol Microbiol Scand 1965;64:31-49.

25. Martin-de-Argila C, Boixeda D, Redondo C, Alvarez I, Gisbert JP, García Plaza A, Cantón R. Relation between histologic subtypes and location of gastric cancer and Helicobacter pylori. Scand J Gastroenterol 1997;32:303-7.

26. Moutinho V, Makino E. Epidemiological features of the gastric cancer in Belém (Brasil). ABCD Arq Bras Cir Dig 1988;3:69-74.

27. Munoz N, Correa P, Cuello C, Duque E. Histologic types of gastric carcinoma in high and low risk areas. Int J Cancer 1968;3:809-18.

28. Munoz N, Connelly R. Time trends of intestinal and diffuse types of gastric cancer in the United States. Int J Cancer 1971;8:158-64.

29. Neugut AJ, Hayek M, Houwe G. Epidemiology of gastric cancer. Semin Oncol 1996;23:281-91.

30. Nogueira AMMF, Ribeiro GM, Rodrigues MAG, Queiroz DMM, Mendes EM, Rocha GA, Barbosa AJA. Prevalence of Helicobacter pylori in Brazilian patients with gastric carcinoma. Anat Pathol 1993;236-9.

31. Nomura A, Stemmermann GN, Chyou PH, Kato I, Perez-Perez GI, Blaser MJ. Helicobacter pylori infectionand gastric carcinoma among Japanese Americans in Hawaii. N Engl J Med 1991;325:1132-6.

32. Parkin DM, Laara E, Muir CS. Estimates of the worldwide frequency of sixteen major cancers in 1980. Int J Cancer 1988;41:184-7.
33. Recavarren-Arce S, Leon-Barua R, Cok J, Berendson R, Gilman RH, RamirezRamos A. Helicobacter pylori and progressive gastric pathology that predisposes gastric cancer. Scand J Gastroenterol 1991;26(suppl.):55-7.

34. Silva S, Filipe MI, Pinho A. Variants of intestinal metaplasia in the evolution of chronic atrophic gastritis and gastric ulcer. A follow-up study. Gut 1990;31:1097-105.

35. Sipponen P, Kekki M, Siurala M. Age-related trends of gastritis and intestinal metaplasia in gastric carcinoma patients and in controls representing in the population at large. Br J Cancer 1984;49:521-30.

36. Sipponen P, Kekki M, Siurala M. The Sidney system: epidemiology and natural history of chronic gastritis. J Gastroenterol Hepatol 1991;6:244-51.

37. Sipponen P, Kosunen TU, Valle J, Riihela M, Seppala K. Helicobacter pylor infection and chronic gastritis in gastric cancer. J Clin Pathol 1992;45:319-23.

38. Sipponen P, Riihela M, Hyvarinen H, Seppala, K. Chronic nonatropic ("superficial") gastritis increases the risk of gastric carcinoma: a case-control study. Scand J Gastroenterol 1994;29:336-40.

39. Valle J, Kekki M, Sipponen P, Ihamaki T, Siurala M. Long-term course and consequences of Helicobacter pylori gastritis: results of a 32-year follow-up study. Scand J Gastroenterol 1996;31:546-50.

40. Wee A, Kang JY, Teh M. Helicobacter pylori and gastric cancer: correlation with gastritis, intestinal metaplasia, and tumor histology. Gut 1992;33:1029-32.

41. Wingo PA, Tong T, Bolden S. Cancer statistics, 1995. Cancer J Clin 199;545:830.

42. Yabuki N, Sasano H, Tobita M, Imatani A, Hoshi T, Kato K, Ohara S, Asaki S, Toyota T, Nagura H. Analysis of cell damage and proliferation in Helicobacter pylori-infected human gastric mucosa from patients with gastric adenocarcinoma. Am J Pathol 1997;151:821-9.
Recebido em 5/4/2001. Aprovado em 28/6/2001 